\title{
Metastazavusio neplokščialąstelinio nesmulkiųjų ląstelių plaučių vẻžio pirmos eilès gydymas pembrolizumabu, pemetreksedu ir platinos vaistiniais preparatais
}

\author{
PEMBROLIZUMAB, PEMETREXED AND PLATINUM FOR THE FIRST-LINE TREATMENT \\ OF METASTATIC NON-SQUAMOUS NON-SMALL-CELL LUNG CANCER
}

\author{
SKAIDRIUS MILIAUSKAS \\ LSMU MA Pulmonologijos klinika
}

\begin{abstract}
Santrauka. Pembrolizumabas - tai pirmasis programuotos ląstelių žūties baltymo (PD-1) inhibitorius, patvirtintas kaip monoterapija pirmos eilès lokaliai išplitusio arba metastazavusio nesmulkiųjų ląstelių plaučių vèžio gydymui, kai navikiniame audinyje nustatoma aukšta programuotos ląstelių žùties baltymo ligando (PD-L1) raiška ( $\geq 50$ proc.) ir nerandama epidermio augimo veiksnio receptoriaus (EGFR) mutacijos arba anaplastinès limfomos receptoriaus tirozino kinazès (ALK) geno translokacijos. Šiuo metu patvirtinta, kad gydymas pembrolizumabu, kartu su chemoterapija pemetreksedu ir platinos vaistiniais preparatais lemia reikšmingai ilgesnị bendrąjị išgyvenamumą, geresnį išgyvenamumą be ligos progresavimo, nepriklausomai nuo PD-L1 raiškos, lyginant tik su chemoterapija, esant metastazavusiam neplokščialąsteliniam nesmulkiųjų ląstelių plaučių véžiui. Ši gydymo schema yra saugi ir gerai toleruojama. Tai yra šiuolaikinis metastazavusio neplokščialąstelinio nesmulkiųjų ląstelių plaučių vèžio pirmos eilès gydymo standartas.

Reikšminiai žodžiai: pembrolizumabas, nesmulkiųjų ląstelių plaučių vėžys, imunoterapija.

Summary. Pembrolizumab is the first programmed death protein 1 (PD-1) inhibitor, approved for the first line locally advanced or metastatic non-small cell lung cancer monotherapy, when tumor express high programmed death-ligand 1 (PD-L1) level ( $\geq 50$ proc.), with no epidermal growth factor receptor (EGFR) or anaplastic lymphoma kinase (ALK) genomic tumor aberrations. It is currently approved that pembrolizumab together with pemetrexed and platinum significantly prolonged overall survival and progression-free survival rates compared with chemotherapy only regardless of PD-L1 expression for the metastatic nonsmall non-squamous cell lung cancer. This treatment regimen is safe and tolerable. This is a standard of modern treatment of metastatic non-small non-squamous cell lung cancer.
\end{abstract}

Keywords: pembrolizumab, non-small cell lung cancer, immunotherapy.

DOI: https://doi.org/10.37499/PIA.765

\section{IVADAS}

Žinoma, kad plaučių vėžys yra viena iš labiausiai paplitusių onkologinių ligų, nulemianti didžiausią mirtingumą [1]. 85 proc. atvejų nustatomas nesmulkiųjų ląstelių plaučių vėžys. Kai plaučių vėžys yra lokaliai išplitęs (ir negalimas spindulinis gydymas) arba metastazavęs, ligos prognozè yra bloga [2]. Šiuo atveju skiriamas tik sisteminis plaučių véžio gydymas. „Sisteminio gydymo“ terminu apibūdinama chemoterapija, taikinių terapija bei imunoterapija. Prieš skiriant plaučių vėžio gydymą, ịvertinami prognostiniai ir predikciniai veiksniai: histologinis tipas, molekuliniai pokyčiai, paciento amžius, funkcinè būkle, gretutinès ligos, svarbi ir pačio paciento nuomonè. Dar visai nesenai iki imunoterapijos atsiradimo chemoterapija platinos vaistinių preparatų pagrindu, nesant epidermio augimo veiksnio receptoriaus (angl. Epidermal Growth Factor Receptor, EGFR) geno mutacijos arba anaplastinès limfomos receptoriaus tirozino kinazès (angl. Anaplastic Lymphoma Kinase, ALK) geno translokacijos, buvo išplitusio nesmulkiųjų ląstelių plaučių vẻžio gydymo standartas, esant galimybei kartu papildomai neplokščiųjų ląstelių plaučių vẻžio pirmos eilès sisteminiam gydymui skirti angiogenezès slopintoją bevacizumabą [3,4]. Imunoterapija - naujas ir veiksmingas plaučių véžio sisteminio gydymo metodas, aktyvinant imuninès sistemos ląsteles, kad šios galètų atpažinti ir sunaikinti vèžio ląsteles. Gydymas 
imuninès sistemos kontrolès inhibibitoriais (angl. immune check point inhibitors), sutrumpintai dažniau vadinamas imunoterapija, ženkliai prailgina pacientu bendrą̧ą gyvenimo trukmę, lemia ilgalaikị atsaką $\mathfrak{i}$ gydymą ir yra gerai toleruojamas. Programuotos ląstelių žũties baltymo ligando (angl. Programmed Deathligand 1, PD-L1) nustatymas sergančiųjų nesmulkiųjų ląstelių plaučiu vėžiu navikiniame audinyje yra svarbus požymis parenkant gydymą. Irodyta, kad PD-L1 raiškos intensyvumas, atliekant imunohistochemini tyrimą, yra susijęs su geru atsaku ị imunoterapiją $[5,6]$.

\section{PEMBROLIZUMABAS NESMULKIŲJŲ LĄSTELIŲ PLAUČIU VĖŽIO GYDYME}

Pembrolizumabas yra monokloninis imunoglobulino (Ig) G4 antikūnas prieš programuotos ląstelès žūties baltymą-1 (angl. Programmed Cell Death Protein-1, PD-1), pagamintas kininio žiurkèno patelès kiaušidžių ląstelèse rekombinantinès DNR technologijos būdu. 2015 m. Jungtinių Amerikos Valstijų Maisto ir vaistų administracija (angl. U.S. Food and Drug Administration, FDA), o vèliau ir Europos vaistų agentūra (agl. European Medicines Agency, EMA) patvirtino pembrolizumabo skyrimą lokaliai išplitusio arba metastazavusio nesmulkiųjų ląstelių plaučių vèžio gydymui, kai liga progresuoja po chemoterapijos platinos pagrindu ir navikiniame plaučiu audinyje nustatoma $\mathrm{PD}-\mathrm{L} 1$ raiška. Remiantis III fazès klinikinio tyrimo KEYNOTE-024 duomenimis, pembrolizumabas reikšmingai lèmè ilgesnę gyvenimo trukmę be ligos progresavimo (angl. progression free survival) ir bendrąji išgyvenamumą (angl. overall survival). 2016 m. pembrolizumabas patvirtintas pirmuoju imunoterapiniu vaistu, kuris skirtas pirmos eilès išplitusio nesmulkiųjų ląstelių plaučių gydymui kaip monoterapija, esant aukštai PDL1 raiškai ( $\geq 50$ proc.) ir neradus EGFR mutacijos arba ALK geno translokacijos [5, 7]. Būtent KEYNOTE-024 tyrimo duomenys pakeitè sergančiųjų lokaliai išplitusiu arba metastazavusiu nesmulkiųjų ląstelių plaučių vẻžio gydymo gaires. Šio tyrimo metu nustatyta gyvenimo trukmè be ligos progresavimo, vertinant tyrimo rezultatus vidutiniškai po 25,2 mèn. stebėsenos, pembrolizumabo grupeje buvo 10,3 mèn. (95 proc. pasikliautinasis intervalas (PI) 6,7 - nepasiekta) ir 6 mèn. (95 proc. PI $4,2-6,2)$ chemoterapijos grupejje (šansų santykis (ك̌S) 0,50 ; 95 proc. PI $0,37-0,68$; p 95 proc. PI $0,37-0,68$; $\mathrm{p}<0,001)$. Pembrolizumabas sergantiesiems išplitusiu arba metastazavusiu nesmulkiųjų ląstelių plaučių věžiu, esant $\geq 50$ proc. PD-L1 raiškai naviko audinyje, 50 proc. sumažino ligos progresavimo ir mirties riziką, lyginant su chemoterapija platinos pagrindu. Išgyvenamumo trukmès mediana pembrolizumabo grupejje siekè 30 mèn. (95 proc. PI 18,3 mèn. - nepasiekta) ir 14,2 mèn. (95 proc. PI 9,8-19 mèn.) chemoterapijos grupejje (ŠS 0,63 ; 95 proc. PI $0,47-0,86 ; \mathrm{p}=0,002$ ) [6]. Tačiau žinoma, kad nesmulkiųjų ląstelių plaučių věžio dalis su aukšta $\mathrm{PD}-\mathrm{L} 1$ raiška ( $\geq 50$ proc.) nèra didelè. Esant išplitusiam nesmulkiųjų ląstelių plaučių vezžiui, liga dažnai greitai progresuoja ir tik mažiau nei pusè visų sergančiųjų gauna antros eilès gydymą $[8,9]$. Da-

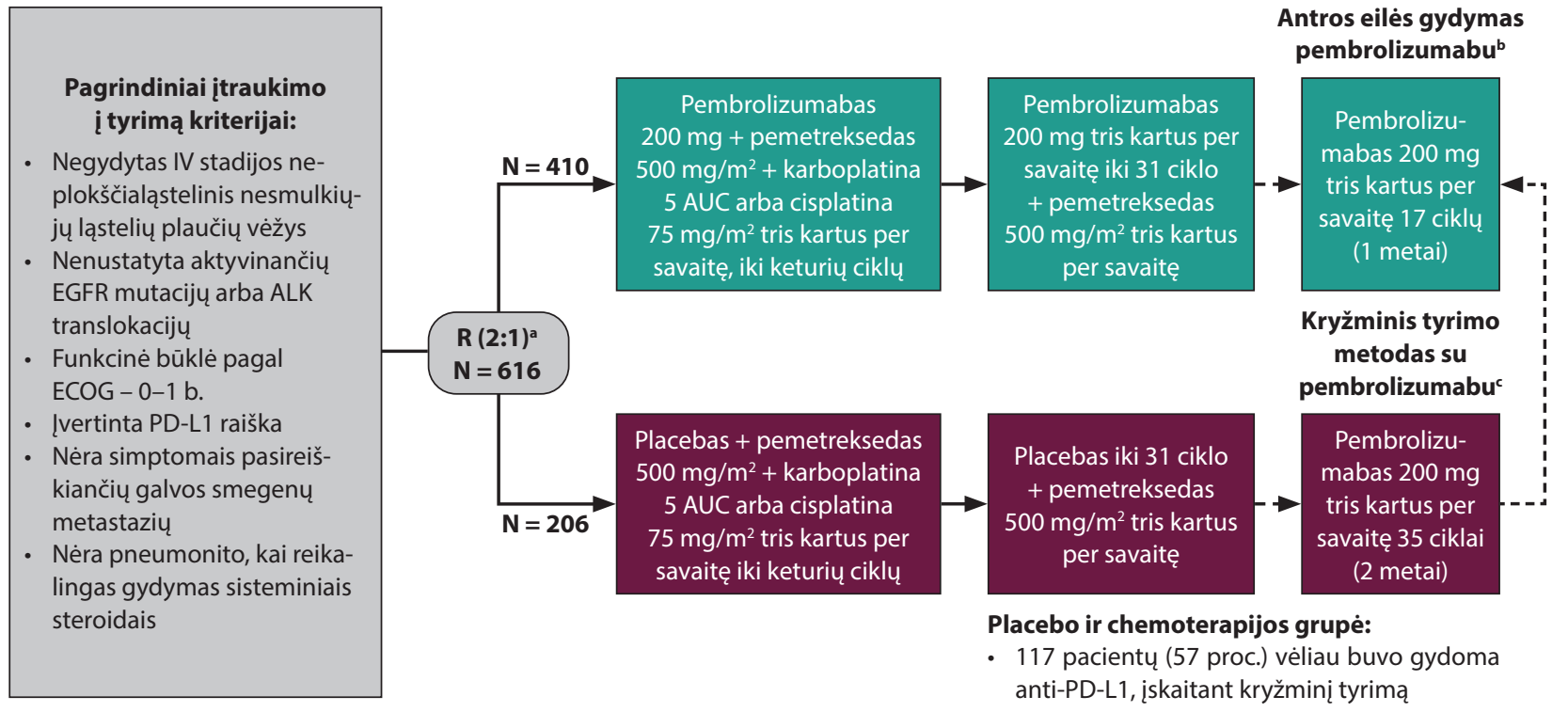

\section{1 pav. Klinikinio tyrimo KEYNOTE-189 dizainas [16]}

${ }^{a}$ Randomizacija buvo vykdyta pagal: PD-L1 raišką ( $\geq 1$ proc., palyginus su <1 proc.), platinos chemoterapiją (cisplatina, palyginus su karboplatina) ir rūkymą

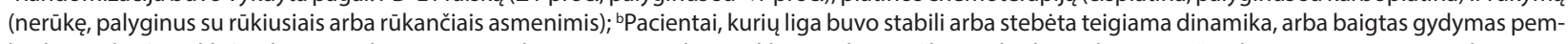
brolizumabu (35 ciklai), arba nutrauktas tyrimo gydymas po $\geq 8$ gydymo ciklų pasiekus visišką atsaką, bet vèliau nustačius ligos progresavimą, galejjo gauti antros eilès gydymą pembrolizumabu 17 ciklų ( 1 metus), jei nuo paskutinès pembrolizumabo dozės taikomas joks kitas naujas priešvėžinis gydymas; cPacientai galejo pereiti prie monoterapijos pembrolizumabu po ligos progresavimo ivertinto pagal RECIST v1.1.

ALK - anaplastinès limfomos receptoriaus tirozino kinaze (angl. Anaplastic Lymphoma Kinase); AUC - plotas po kreive (angl. area under the curve); ECOG Rytų kooperatinès onkologijos grupès (angl. Eastern Cooperatyve Oncology Group) pasiūlyta pacientų funkcinès būklès vertinimo skalè; EGFR - epidermio augimo veiksnio receptorius (angl. Epidermal Growth Factor Receptor). 


\section{Farmakoterapija}

bar jau žinoma, kad pirmos eilès gydymas derinant chemoterapiją ir imunoterapiją, padidina atsako i̇ gydymą tikimybę ir gerina išgyvenamumą. Imuninio atsako moduliavimas slopinant PD-1 sustiprinamas imunogenetiniais citotoksinès chemoterapijos poveikiais. Pavyzdžiui, gerèja antigenų kryžminis pateikimas („prezentacija“), kurị, ịvykus naviko ląstelių destrukcijai, atlieka dendritinès ląstelès ir kt. [10].

2017 m., kai KEYNOTE-021 antros fazès klinikiniame tyrime buvo gautas ryškus bendrojo atsako i gydymą pagerejimas (angl. overall response rate), lyginant su gydymu tik su pemetreksedu ir karboplatina, FDA patvirtino pirmos eilès gydymo pembrolizumabu derinant su pemetreksedu ir karboplatina skyrimo indikaciją esant išplitusiam nesmulkiųjų neplokščiųjų ląstelų plaučiu vèžiui [11, 12]. Žymiai geresnis pembrolizumabo, derinant su pemetreksedu ir karboplatina, gydymo schemos poveikis vèliau buvo patvirtintas ir pagrindiniu trečios fazès KEYNOTE-189 klinikiniu tyrimu [13, 14]. Šio tyrimo pagrindu EMA 2018 m. patvirtino indikaciją, kad pembrolizumabas yra skiriamas derinyje su chemoterapija pemetreksedu ir platinos vaistiniais preparatais metastazavusio neplokščialąstelinio nesmulkiụjų ląstelių plaučių vẻžio pirmaeiliam gydymui suaugusiesiems, kurių navikuose nenustatyta EGFR mutacija arba ALK translokacija nepriklausomai nuo PD-L1 raiškos.

KEYNOTE-189 dvigubai aklame trečios fazès klinikiniame tyrime 616 negydytų sergančiųjų metastazavusiu nesmulkiųjų neplokščiųjų ląstelių plaučių vė̌ziu buvo atsitiktinai suskirstyti santykiu 2:1 (nesant EGFR aktyvinančių mutacijų arba ALK translokacijų) i̇ dvi gydymo grupes: 1) chemoterapija, skriant pemetreksedą su platinos vaistiniu preparatu ir pembrolizumabu; 2) chemoterapija skiriant pemetreksedą su platinos vaistiniu preparatu ir placebu (1 pav.). Pembrolizumabas (antroje gydymo grupeje vietoj pembrolizumabo buvo skiriamas placebas) ir chemoterapija buvo skiriamas 200 mg dozèmis kas tris savaites (iš viso 4 kursai), po to ji tęsiant palaikomajam gydymui su pemetreksedu iki 35 kursų. Pembrolizumabo grupejje, patvirtinus ligos progresavimą, buvo galimas gydymas tik pembrolizumabu. Pagrindiniai KEYNOTE-189 tyrimo tikslai buvo bendrasis išgyvenamumas ir išgyvenamumas be ligos progresavimo. Radiologiniai tyrimai vertinti centralizuotai. Praejjus vidutinei 10,5 mèn. stebėsenos duomenys

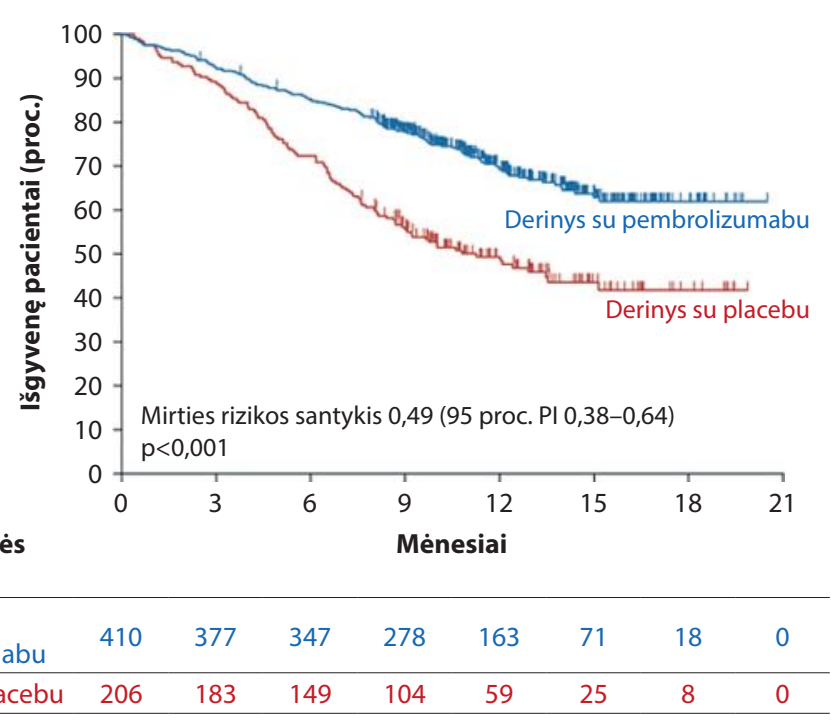

2 pav. KEYNOTE-189: pradiniai bendrojo išgyvenamumo duomenys

PI - pasikliautinasis intervalas.

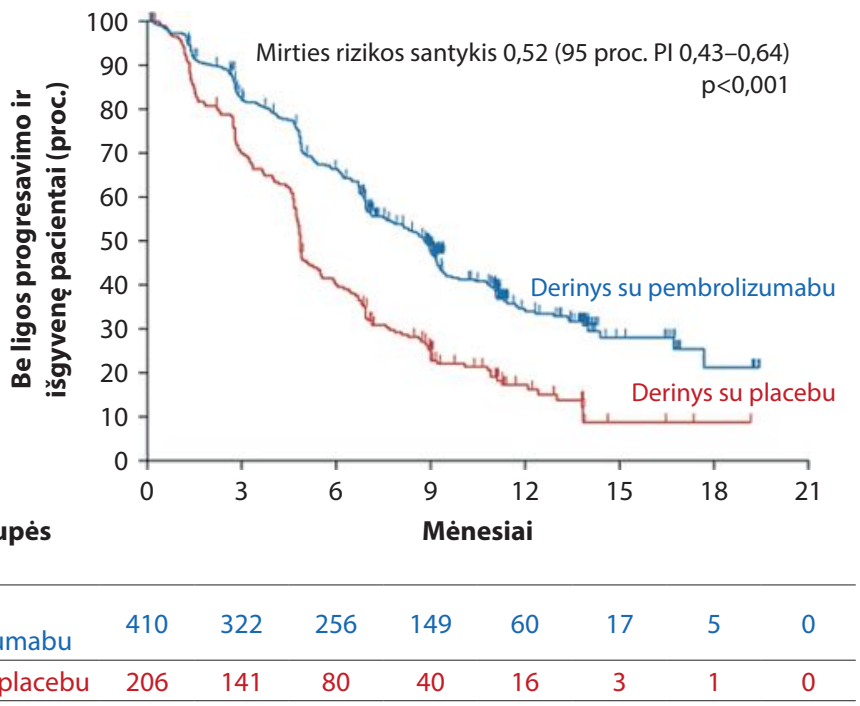

3 pav. KEYNOTE-189: pradiniai išgyvenamumo be ligos progresavimo

trukmei, pembrolizumabu su chemoterapija gydymo grupejje, vertinant pradinius tyrimo duomenis, 12 mèn. išgyveno 69,2 proc. (95 proc. PI 64,1-73,8) tiriamųjų, lyginant su 49,4 proc. ( 95 proc. PI, $42,1-56,2$ ) placebo grupeje (mirties ŠS buvo 0,49; 95 proc. PI $0,38-0,64$; $\mathrm{p}<0,001)$ (2 pav.). Svarbu tai, kad ryškus bendrojo išgyvenamumo, tiek ir išgyvenamumo be ligos progresavimo pagerejimas buvo konstatuotas visose PD-L1 raiškos kategorijose. Vidutinis išgyvenamumas be ligos progresavimo buvo 8,8 mèn. (95 proc. PI $7,6-9,2)$ pembrolizumabo su chemoterapija ir 4,9 mèn. (95 proc. PI 4,7-5,5) placebo su chemoterapija grupèse (ligos progresavimo arba mirties ŠS 0,$52 ; 95$ proc. PI 0,43-0,64; $\mathrm{p}<0,001)$ (3 pav.). Nepageidaujamų poveikių dèl bet kokios priežasties nepriklausomai nuo skiriamo gydymo abiejose grupèse buvo registruota 
atitinkamai - 99,8 proc. ir 99 proc. atvejų. Trečiojo ir didesnio laipsnio nepageidaujami poveikiai registruoti atitinkamai - 67,2 proc. ir 65,8 proc. tiriamųju. Dèl nepageidaujamų poveikių gydymas visais klinikinio tyrimo vaistais nutrauktas 13,8 proc. pembrolizumabo su chemoterapija grupès ir 7,9 proc. placebo su chemoterapija grupès pacientų.

Šiais metais paskelbtoje KEYNOTE-189 aposteriorineje (post hoc) analizèje nurodoma, kad dauguma trečiojo ir didesnio laipsnio nepageidaujamų poveikių pirmą kartą registruoti per 3 mén. nuo vaisto pirmo paskyrimo klinikinio tyrimo pradžioje ir baigèsi per dvi savaites nuo atsiradimo pradžios [15]. Daugumoje atvejų gydymas dèl nepageidaujamų poveikių nutrauktas pirmųjų keturių gydymo kursų metu. Šie duomenys leidžia daryti prielaidą, kad toksiškumas vèlesnio gydymo metu nesikaupia. Todèl reikalinga labai atidžiai vertinti ir spręsti, ar verta nutraukti palaikomąji gydymą pemetreksedu, esant galimai aiškiai gydymo pemetreksedu (derinant su pembrolizumabu) naudai.

Šiais metais vykusiame virtualiame $\mathrm{Pa}-$ sauliniame plaučių vèžio kongrese (angl. IASLC World Conference on Lung Cancer) paskelbti atnaujinti keturių metų stebe்senos KEYNOTE-189 tyrimo duomenys [16]. Klinikinio tyrimo duomenų gavimo

\begin{tabular}{l|c|l}
\multicolumn{3}{c}{ PD-L1 raiška $\geq \mathbf{5 0}$ proc. } \\
\hline $\begin{array}{l}\text { Pembrolizumabas } \\
\text { derinyje } \\
\text { su chemoterapija }\end{array}$ & Atvejai & Mediana (95 proc. PI) \\
\hline $\begin{array}{l}\text { Placebas derinyje } \\
\text { su chemoterapija }\end{array}$ & 72,9 proc. & 27,7 mèn. $(20,4-38,2)$ \\
\hline
\end{tabular}

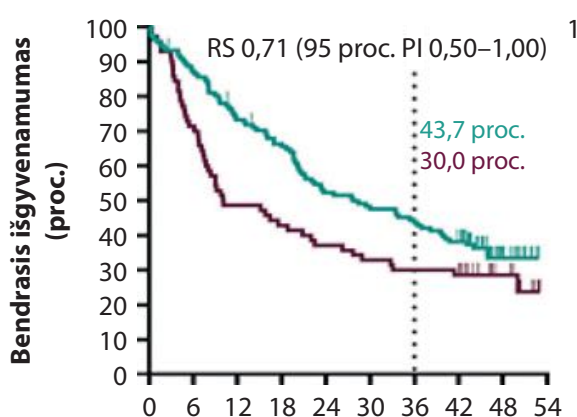

\begin{tabular}{lcccc}
$\begin{array}{l}\text { Rizikos grupès } \\
\text { pacientai }\end{array}$ & \multicolumn{4}{l}{ Laikotarpis, mènesiais } \\
\hline $\begin{array}{l}\text { Pembrolizumabas } \\
\text { derinyje su } \\
\text { chemoterapija }\end{array}$ & 132 & 85 & 56 & 0 \\
\hline $\begin{array}{l}\text { Placebas derinyje } \\
\text { su chemoterapija }\end{array}$ & 70 & 30 & 21 & 0 \\
\hline
\end{tabular}

data (angl. cut-off date) - $2020 \mathrm{~m}$. rugpjūčio 28 diena. Ketvirtame paveiksle pateikiami bendrojo išgyvenamumo duomenys, penktame paveiksle - pagal PD-L1 raišką. Atitinkami išgyvenamumo be ligos progresavimo duomenys pateikiami šeštame ir septintame paveiksluose. Autoriai pateikia išvadas, kad, atliekant ilgalaikę KEYNOTE-189 tyrimo pacientų stebėseną

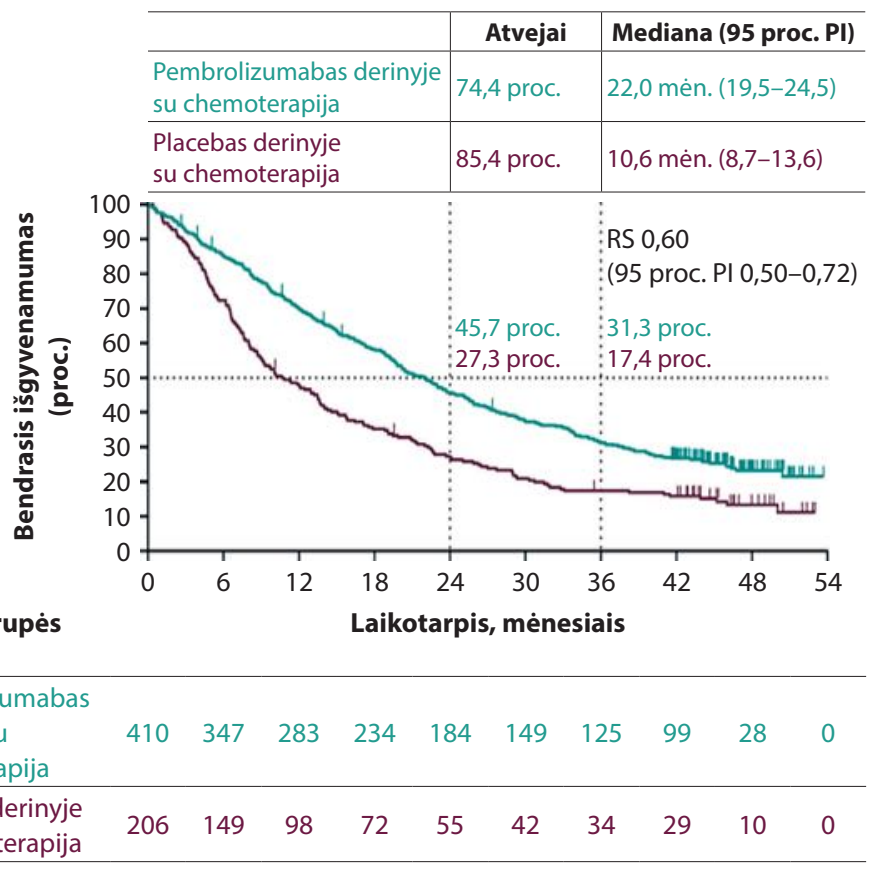

4 pav. Naujausi KEYNOTE-189 bendrojo išgyvenamumo duomenys [16] $\mathrm{PI}$ - pasikliautinasis intervalas; RS - rizikos santykis.

\begin{tabular}{c|l}
\multicolumn{2}{c}{ PD-L1 raiška 1-49 proc. } \\
\hline Atvejai & Mediana (95 proc. $\mathbf{P I )}$ \\
\hline 76,6 proc. & 21,8 mèn. $(17,7-25,6)$ \\
\hline 89,7 proc. & 12,1 mèn. $(8,7-19,4)$ \\
\hline
\end{tabular}

\begin{tabular}{c|l}
\multicolumn{2}{c}{ PD-L1 raiška < 1 proc. } \\
\hline Atvejai & Mediana (95 proc. PI) \\
\hline 81,1 proc. & 17,2 mèn. $(13,8-22,8)$ \\
\hline 92,1 proc. & 10,2 mèn. $(7,0-13,5)$ \\
\hline
\end{tabular}
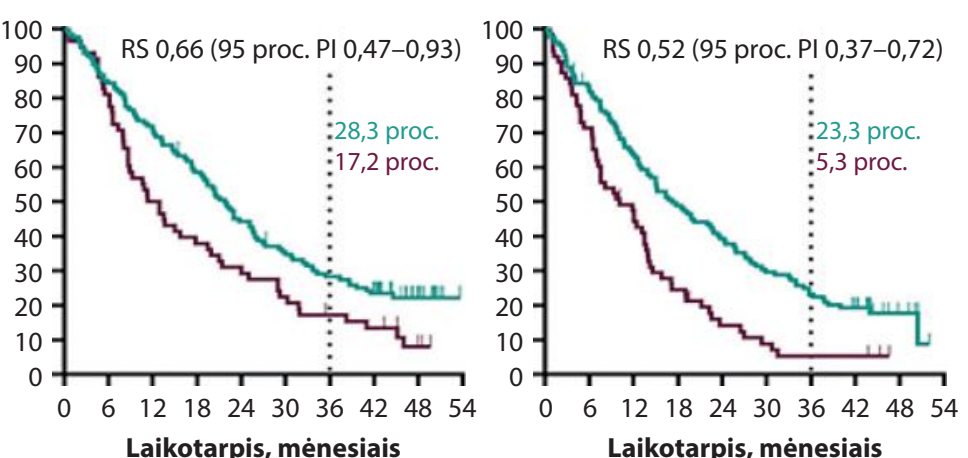

\begin{tabular}{llll}
128 & 74 & 35 & 0 \\
\hline 58 & 22 & 9 & 0
\end{tabular}

\begin{tabular}{llll}
127 & 61 & 29 & 0 \\
\hline 63 & 15 & 3 & 0 \\
\hline
\end{tabular}

5 pav. Naujausi KEYNOTE-189 bendrojo išgyvenamumo duomenys pagal PD-L1 raišką [16]

$\mathrm{PI}$ - pasikliautinasis intervalas; RS - rizikos santykis. 


\section{Farmakoterapija}

(daugiau nei trejus metus), išlieka ir tęsiasi aiški pembrolizumabo su chemoterapija pemetreksedu ir platinos vaistiniais preparatais sergantiesiems metastazavusiu nesmulkiųjų neplokščiųjų ląstelių plaučių vėžiu be aktyvinančių EGFR mutacijų ir ALK translokacijų gydymo nauda. Bendrojo išgyvenamumo bei išgyvenamumo be ligos progresavimo pagerejjimas nepriklauso nuo pradinès PD-L1 raiškos. Trejų metų bendrasis išgyvenamumas tyrimo grupése buvo atitinkamai - 31,3 ir 17,4 proc. Tiriamiesiems, kurie gavo 35 pembrolizumabo gydymo kursus, toliau stebimas besitęsiantis atsakas. Gydymas pembrolizumabu, derinant su pemetreksedu ir platinos vaistiniais preparatais, pasižymi geru saugumo profiliu.

Yra žinoma, kad šiuo metu metastazavusio nesmulkiųjų neplokščiųjų ląstelių plaučių vėžio, nesant EGFR aktyvinančių mutacijų arba ALK translokacijų sisteminiam pirmos eilès gydymui yra patvirtinta ir keturių vaistų (atezolizumabo, bevacizumabo, paklitakselio ir karboplatinos) schema. III fazès IMpower 150 klinikinis tyrimas parodè, kad pirmos eilès gydymas atezolizumabu, karboplatina, paklitakseliu ir bevacizumabu statistiškai reikšmingai pagerino bendrąjį išgyvenamumą (ŠS 0,78; 95 proc. PI $0,64-0,96 ; \mathrm{p}=0,020)$ ir tyrèjų vertinamą išgyvenamumą be ligos progre- savimo (ŠS 0,62; 95 proc. PI 0,52-0,74; p<0,001) [17]. Šių dviejų gydymo galimybių skirtumų suvokimas yra labai svarbus priimant klinikinius sprendimus, ypač kai norima palyginti bendrąj̣ išgyvenamumą bei išgyvenamumą be ligos progresavimo, taip pat vertinant saugumą bei gydymo kainą. Nepaisant to, kad

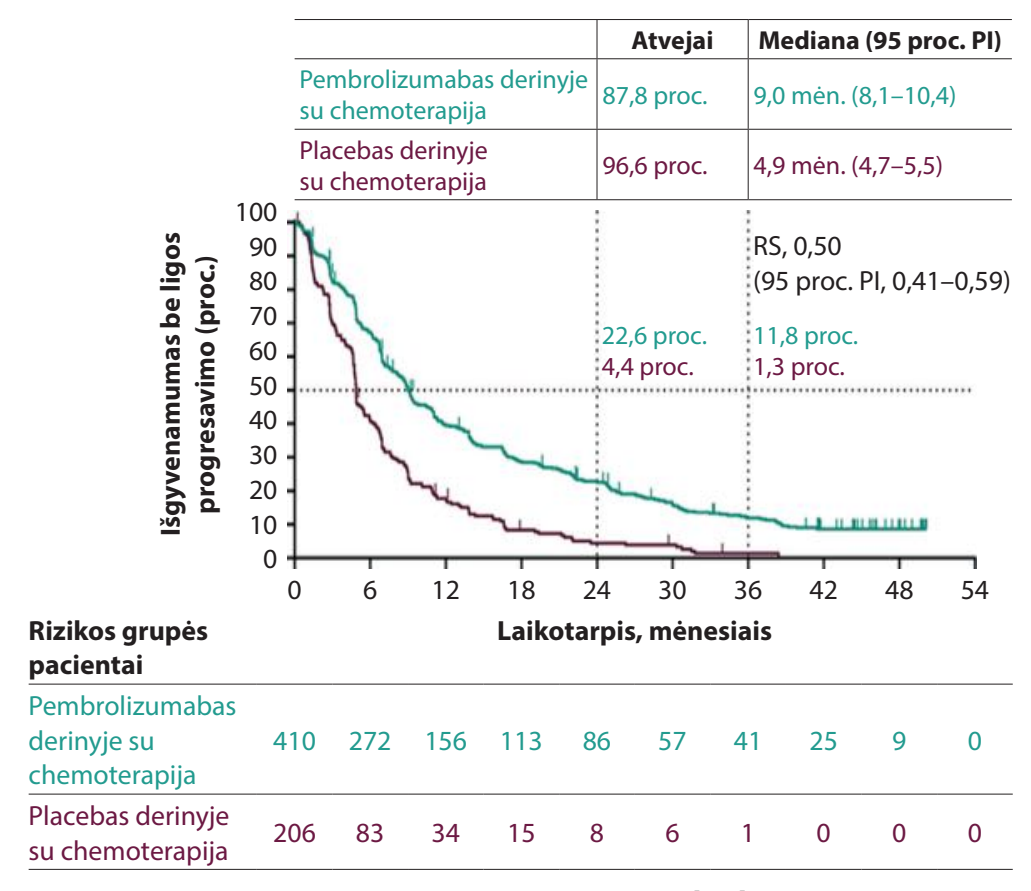

6 pav. Naujausi KEYNOTE-189 išgyvenamumo be ligos progresavimo duomenys [16]

$\mathrm{PI}$ - pasikliautinasis intervalas; RS - rizikos santykis.

\begin{tabular}{l|c|l} 
& \multicolumn{2}{c}{ PD-L1 raiška $\geq \mathbf{5 0}$ proc. } \\
\hline $\begin{array}{l}\text { Pembrolizumabas } \\
\text { derinyje } \\
\text { su chemoterapija }\end{array}$ & 80,3 proc. & 11,1 mèn. $(9,1-16,4)$ \\
\hline $\begin{array}{l}\text { Placebas derinyje } \\
\text { su chemoterapija }\end{array}$ & 95,7 proc. & 4,8 mèn. $(3,1-6,2)$ \\
\hline
\end{tabular}
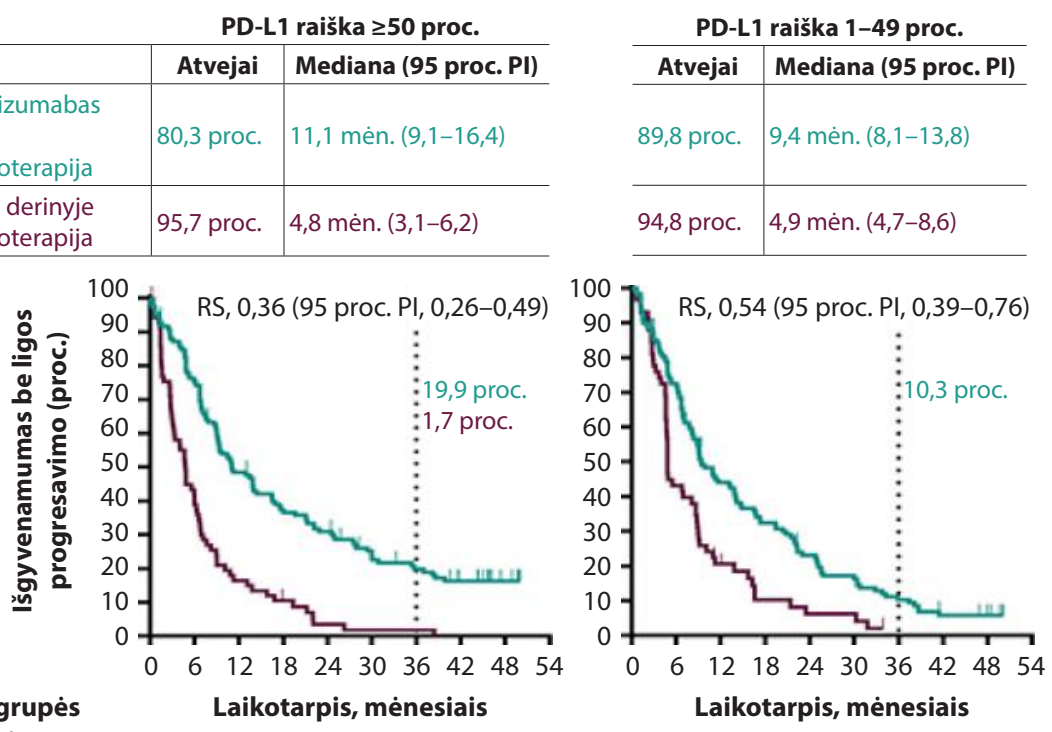

\begin{tabular}{lcccc}
$\begin{array}{l}\text { Rizikos grupès } \\
\text { pacientai }\end{array}$ & \multicolumn{4}{l}{ Laikotarpis, mènesiais } \\
\hline $\begin{array}{l}\text { Pembrolizumabas } \\
\text { derinyje su } \\
\text { chemoterapija }\end{array}$ & 132 & 47 & 22 & 0 \\
\hline $\begin{array}{l}\text { Placebas derinyje } \\
\text { su chemoterapija }\end{array}$ & 70 & 6 & 1 & 0 \\
\hline
\end{tabular}

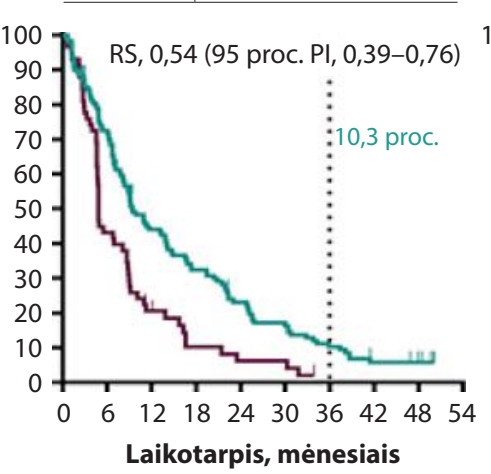

\begin{tabular}{llll}
128 & 39 & 12 & 0 \\
\hline 58 & 5 & 0 & 0
\end{tabular}
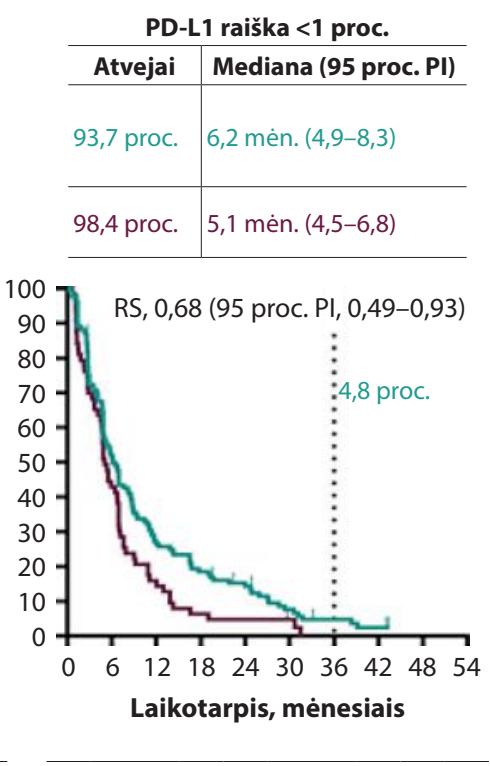

\begin{tabular}{llll}
127 & 23 & 4 & 0 \\
\hline 63 & 4 & 0 & 0 \\
\hline
\end{tabular}

7 pav. Naujausi KEYNOTE-189 išgyvenamumo be ligos progresavimo duomenys pagal PD-L1 raišką [16]

$\mathrm{PI}$ - pasikliautinasis intervalas; RS - rizikos santykis. 
pembrolizumabas su chemoterapija ir atezolizumabas su chemoterapija +/- bevacizumabas klinikiniuoe tyrimuose parodė aiškią naudą, joks klinikinis tyrimas šių dviejų gydymo režimų tiesiogiai (angl. head to head) niekada nelygino. Tokio klinikinio tyrimo dizaino sukūrimas ir ịvykdymas pareiklautų didelių sąnaudų, reikètų didelès tiriamųjų imties ir tektų ilgai laukti, kol būtų gauti patikimi rezultatai. Abu gydymo režimai lyginti netiesiogiai, atrenkant tinkamus atvejus (angl. matching-adjusted indirect comparison) naudojant turimus prieinamus klinikinių tyrimų duomenis [18]. Palyginimui naudota KEYNOTE-021 G kohortos (KN021 G) (pembrolizumabas + karboplatina + pemetreksedas; $\mathrm{N}=59$ ), KEYNOTE-189 (KN189) (pembrolizumabas + pemetreksedas + platina; $\mathrm{N}=$ 410) duomenys, publikuoti sujungti duomenys iš IMpower 130 (atezolizumabas + karboplatina + nabpaklitakselis; $\mathrm{N}=451$ ) ir IMpower 150 (atezolizumabas + karboplatina + paclitakselis + bevacizumabas; $\mathrm{N}=356$ ) tyrimų. Apibendrindami šios analizès rezultatus, autoriai nurodo didesnę gydymo pembrolizumabu su chemoterapija naudą bendrajam išgyvenamumui ir išgyvenamumui be ligos progresavimo. Saugumo profilis nelygintas ir nevertintas.

\section{APIBENDRINIMAS}

Nesmulkiųjų neplokščiųjų ląstelių plaučių vẻžio gydymas pembrolizumabu kartu su chemoterapija pemetreksedu ir platinos vaistiniais preparatais lemia reikšmingai ilgesnị bendrajji išgyvenamumą, geresnị išgyvenamumą be ligos progresavimo, nepriklausomai nuo PD-L1 raiškos, lyginant tik su chemoterapija, esant metastazavusiam neplokščialąsteliniam nesmulkiųjų ląstelių plaučių vèžiui. Ši gydymo schema yra saugi ir gerai toleruojama. Tai yra šiuolaikinis metastazavusio neplokščialąstelinio nesmulkiųjų ląstelių plaučių vėžio pirmos eilès gydymo standartas.

LT-KEY-0012

\section{LITERATŪRA}

1. Bray F, Ferlay J, Soerjomataram I, Siegel RL, Torre LA, Jemal A. Global cancer statistics 208: GLOBOCAN estimates of incidence and mortality worldwide for 36 cancers in 185 countries. CA Cancer J Clin. 2018; 68(6):394-424.

2. Zappa C, Mousa SA. Non-small cell lung cancer: current treatment and future advances, Transl. Lung Cancer Res. 2016; 5(3):288-300.

3. Reck M. Pembrolizumab as first-line therapy for metastatic non-small-cell lung cancer. Immunotherapy. 2018;10(2):93-105.

4. Peters S, Reck M, Smit EF, Mok T, Hellmann MD. How to make the best use of immunotherapy as first-line treatment of advanced/metastatic non-small-cell lung cancer. Ann Oncol. 2019;30(6):884-96.

5. Reck M, Rodríguez-Abreu D, Robinson AG, Hui R, Csőszi T, Fülöp A, et al. Pembrolizumab versus chemotherapy for PD-L1-positive non-small-cell lung cancer. N Engl J Med. 2016; 375(19):1823-33.

6. Reck M, Rodríguez-Abreu D, Robinson AG, Hui R, Csőszi T, Fülöp A, et al. Updated analysis of KEYNOTE-024: pembrolizumab versus platinum-based chemotherapy for advanced non-small-cell lung cancer with $\mathrm{PD}$-L1 tumor proportion score of 50\% or greater. J Clin Oncol. 2019; 37(7):537-46.

7. U.S. Food and Drug administration. Pembrolizumab (KEYTRUDA) checkpoint inhibitor. Available at: http://www. fda.gov.

8. Davies J, Patel M, Gridelli C, de Marinis F, Waterkamp D, McCusker ME. Realworld treatment patterns for patients receiving second-line and third-line treatment for advanced non-small cell lung cancer: a systematic review of recently published studies. PLoS One 2017; 12(4):e0175679.

9. Lazzari $C$, Bulotta $A$, Ducceschi M, Viganò MG, Brioschi E, Corti F, et al. Historical Evolution of Second-line Therapy in Non-small Cell Lung Cancer. Front Med (Lausanne). 2017:4:4.

10. Bracci L, Schiavoni G, Sistigu A, Belardelli F. Immune-based mechanisms of cytotoxic chemotherapy: implications for the design of novel and rationale-based combined treatments against cancer. Cell Death Differ. 2014:21:15-25.

11. Borghaei H, Langer CJ, Gadgeel S, Papadimitrakopoulou VA, Patnaik A, Powell SF, et al. 24-Month Overall Survival from KEYNOTE-021 Cohort G: Pemetrexed and Carboplatin with or without Pembrolizumab as First-line Therapy for Advanced Nonsquamous Non-small Cell Lung Cancer. J Thorac Oncol. 2019;14(1):124-9.

12. Langer CJ, Gadgeel SM, Borghaei H, Papadimitrakopoulou VA, Patnaik A, Powell SF, et al. Carboplatin and pemetrexed with or without pembrolizumab for advanced, non-squamous non-small-cell lung cancer: a randomised, phase 2 cohort of the open-label KEYNOTE-021 study. Lancet Oncol. 2016;17(11):1497-508.

13. Gadgeel S, Rodríguez-Abreu D, Speranza G, Esteban E, Felip E, Dómine M, et al. Updated Analysis From KEYNOTE-189: Pembrolizumab or Placebo Plus Pemetrexed and Platinum for Previously Untreated Metastatic Nonsquamous Non-small-cell Lung Cancer. J Clin Oncol. 2020;38(14):1505-17.

14. Gandhi L, Rodríguez-Abreu D, Gadgeel S, Esteban E, Felip E, De Angelis F, et al. Pembrolizumab plus Chemotherapy in Metastatic Non-small-cell Lung Cancer. N Engl J Med. 2018;378(22):2078-92.

15. Garon EB, Aerts J, Kim JS, Muehlenbein CE, Peterson P, Rizzo MT, et al. Safety of pemetrexed plus platinum in combination with pembrolizumab for metastatic nonsquamous nonsmall cell lung cancer: A post hoc analysis of KEYNOTE-189. Lung Cancer. 2021:155:53-60.

16. Gray JE, Rodriguez-Abreu D, Powell SF,Hochmair MJ, Gadgeel S, Esteban E, et al. Pemrolizumab+Pemetrexed-Platinum for metastatic NSCLC: 4-year follow-up for KEYNOTE-189. Scientific thesis. J Thorac Oncol. 2021; 16(35):S224. Available at: https://www.jto.org/article/S1556-0864(21)00183-0/fulltext.

17. Socinski MA, Jotte RM, Cappuzzo F, Orlandi F, Stroyakovskiy D, Nogami N, et al. Atezolizumab for First-line Treatment of Metastatic Nonsquamous NSCLC. N Engl J Med. 2018;378(24):2288-301.

18. Halmos B, Burke T, Kalyvas C, Vandormael K, Frederickson A, Piperdi B. Pembrolizumab+chemotherapy versus atezolizumab+chemotherapy+/-bevacizumab for the first-line treatment of non-squamous NSCLC: A matching-adjusted indirect comparison. Lung Cancer. 2021:155:175-82. 